\title{
Sickle Cell Disease
}

National Cancer Institute

\section{Source}

National Cancer Institute. Sickle Cell Disease. NCI Thesaurus. Code C34383.

A blood disorder characterized by the appearance of sickle-shaped red blood cells and anemia. 